\title{
Fumigation of Stored Pome Fruit with Hexanal Reduces Blue and Gray Mold Decay
}

\author{
Peter L. Sholberg ${ }^{1}$ and Paul Randall \\ Agriculture and Agri-Food Canada, Pacific Agri-Food Research Centre, Box \\ 5000, 4200 Highway 97, Summerland, British Columbia, Canada V0H 1 Z0
}

Additional index words. Botrytis cinerea, Penicillium expansum, cyprodinil

Abstract. Stored apples and pears are subject to blue and gray mold decay incited by Penicillium expansum and Botrytis cinerea respectively. Hexanal, a $\mathrm{C} 6$ carbon aldehyde, used as a vapor provided effective control of both blue and gray molds in laboratory experiments on apple slices. A preliminary trial with 'Anjou' pears in bins showed that hexanal was not corrosive and could reduce gray mold in pears stored for 7 months. However details on the correct procedure for fumigating pome fruit were lacking, and further studies were needed to develop a reliable fumigation strategy. In trials with inoculated fruit, hexanal inactivated conidia of $B$. cinerea contaminating the pear surface when used at a rate of $2 \mathrm{mg} \cdot \mathrm{L}^{-1}$ for 24 hours or $4 \mathrm{mg} \cdot \mathrm{L}^{-1}$ for 18 hours. It was less effective on 'Gala' apples inoculated with conidia of $P$. expansum, but reduced blue mold decay to low levels at $15^{\circ} \mathrm{C}$. On the other hand, hexanal increased gray and blue molds when used after wounds were made in inoculated fruit. The use of a preharvest treatment with cyprodinil $\left(0.62 \mathrm{~g} \cdot \mathrm{L}^{-1}\right)$ reduced both blue and gray molds in wounds with or without hexanal fumigation. Thus a strategy for controlling postharvest decay was developed by which fruit were treated 2 weeks before harvest with cyprodinil, followed by fumigation with hexanal immediately after harvest. The use of this strategy on 'Anjou' pears produced the highest number of mold-free fruit in 2003 and the least amount of gray and blue mold decay in 2003 and 2004 on pears stored for 4 months. Wounded apples only developed $1 \%$ rot compared with $10 \%$ in the control, indicating that hexanal fumigation of stored apples reduced contamination. Monitoring hexanal during fumigation showed that hexanal concentration declined slowly over a 24 -hour period and could accurately be described by a third-order polynomial equation. Hexanal fumigation at low rates (2$3 \mathbf{~ m g} \cdot \mathrm{L}^{-1}$ ) was not phytotoxic and improved aroma in 'Anjou' pears and 'Gala' apples with no harmful effects on apple or pear firmness, $\mathrm{pH}$, titratable acidity, or soluble solids.

Hexanal is a naturally occurring, volatile C-6 aldehyde formed via the lipoxygenase pathway in plants from linoleic acid (Hildebrand, 1989). Volatiles formed by this pathway in wounded plants have antifungal properties, as shown by early research with wounded tomato leaves in which hyphae of both Alternaria alternata and Botrytis cinerea were inhibited (Hamilton-Kemp et al., 1992). In trials conducted on $B$. cinerea, the related compound $(E)$-2-hexenal, which differs by having a double bond, was more effective against spores than mycelium of the fungus and stimulated its growth at low concentrations (Fallik et al., 1998). Thus, it was concluded that maintenance of a high vapor-phase level of $(E)$-2-hexenal was necessary to inhibit mycelial growth and to avoid enhancing postharvest mold problems.

\footnotetext{
Received for publication 20 Oct. 2006. Accepted for publication $10 \mathrm{Jan} .2007$.

Funded by the Winter Pear Control Committee of the Washington Tree Fruit Research Commission and the matching initiatives program of Agriculture and Agri-Food Canada.

We thank Trevor Shephard and Peter Sanderson for assistance during the early phases of this research. ${ }^{1}$ To whom reprint requests should be addressed; e-mail sholbergp@agr.gc.ca
}

Botrytis cinerea causes the postharvest disease known as gray mold and is considered one of the most important diseases of stored pears. Wounds or injuries are the primary infection courts for the initiation of gray mold in apples and pears (Rosenberger, 1990). The fungus forms a nest rot by growing from infected to healthy fruit at storage temperatures as low as $-0.6{ }^{\circ} \mathrm{C}$ (Ogawa and English, 1991). Lennox et al. (2004) reported that, on 'Anjou' pears, incidence of stem-end gray mold was higher than calyx-end and puncture gray mold. Archbold et al. (1997) showed that hexanal, among other lipoxygenase pathway products, exhibited potential as postharvest fumigants for control of B. cinerea. Subsequent studies showed that when 'Crimson Seedless' table grapes were fumigated with $(E)$-2-hexenal, gray mold was suppressed but not completely controlled (Archbold et al., 1999).

Penicillium expansum Link causes the postharvest disease known as blue mold and is considered the most important disease of stored apples (Turechek, 2004). Hexanal vapor was successfully used to control $P$. expansum on apple slices after $48 \mathrm{~h}$ of continuous exposure to $100 \mathrm{ppm}$ of the product (Song et al., 1996). When the fungus was allowed to grow for $48 \mathrm{~h}$ in air, a subsequent treatment with 450 ppm stopped growth completely (Song et al., 1998). Fan et al. (2006) found that under similar conditions of constant exposure to hexanal, $P$. expansum lesion development on whole apples was reduced. These antimicrobial results are supported by Lanciotti et al. (1999), who found that hexanal strongly inhibited molds, yeasts, and mesophilic and psychrophilic bacteria, and extended the shelf life of apple slices. Hexanal has also been used to control postharvest decay in stone fruit incited by Monilinia laxa and Rhizopus stolonifer (Caccioni et al., 1995).

Hexanal has other properties in addition to its antimicrobial activity. Aroma volatiles are important sensory attributes of ripe fruit, but may also play functional roles in plant-pathogen interactions (Archbold et al., 2000). Hexanal treatment stimulated aroma production in 'Jonagold' and 'Golden Delicious' apple slices (Song et al., 1996, 1998). When added to modified atmosphere (MA) $\left(70 \% \mathrm{~N}_{2}\right.$ and $30 \% \mathrm{CO}_{2}$ ), hexanal also prevented a browning reaction for $16 \mathrm{~d}$ at $15^{\circ} \mathrm{C}$ (Lanciotti et al., 1999).

The goal of this study was to determine whether hexanal vapor could be used as a fumigant to prevent postharvest decay incited by either $B$. cinerea or $P$. expansum on stored apples and pears. To accomplish this objective, small quantities of inoculated fruit were fumigated to establish optimum rate, temperature, and duration for fumigation before and after fruit were wounded. Preharvest treatment of fruit in the orchard with cyprodinil was also evaluated because it was thought unlikely that hexanal would control pathogen conidia in wounds, and cyprodinil had previously been shown to be effective in preventing $B$. cinerea decay in wounds of fruit stored for 3 months (Sholberg et al., 2003a). Larger volumes of fruit were used in subsequent experiments to determine whether hexanal alone or a combination of cyprodinil and hexanal could be used for control of postharvest decay in stored fruit. Characteristics of hexanal such as concentration during fumigation, effect on fruit quality and aroma, and possibility of causing fruit damage were also studied. A preliminary report on the use of hexanal fumigation for control of postharvest decay of pome fruit has been published (Sholberg and Randall, 2005).

\section{Materials and Methods}

\section{Decay control}

Control of gray mold in inoculated 'Anjou' pears. 'Anjou' pears from the Pacific Agri-Food Research Center, Summerland, B.C., research orchard (PARC) were treated with $0,0.31$, or $0.62 \mathrm{~g} \cdot \mathrm{L}^{-1}$ cyprodinil (Vangard 75 WP, Syngenta Crop Protection Canada, Guelph, Ont., Canada) 2 weeks before harvest according to a completely randomized block design on 13 Sept. 2002. (The current label in the United States is for a preharvest interval of $72 \mathrm{~d}$ on apples.) Five single-tree replicates were sprayed until runoff with a backpack sprayer. Subsamples of 10 pears/treatment were used in the inoculated fumigation 
experiments. Botrytis cinerea Pers. was grown on potato dextrose agar (PDA) in plastic (10-cm diameter) Petri plates at $18{ }^{\circ} \mathrm{C}$ for 2 to 3 weeks and was used to make a spore suspension containing $1 \times 10^{4}$ colonyforming units $(\mathrm{CFU}) \cdot \mathrm{mL}^{-1}$. The following procedure was followed: all fruit were inoculated, then either fumigated and wounded or alternatively wounded and fumigated. Specifically, the spore suspension was misted on each fruit with an airbrush (Paache Airbrush Company, Harwood Heights, Ill.). After the spores had dried, the fruit was placed in specially constructed 23-L chambers previously used for evaporating vinegar (Sholberg et al., 2000), and were fumigated for $18 \mathrm{~h}$ with $4 \mathrm{mg} \cdot \mathrm{L}^{-1}$ or $24 \mathrm{~h}$ with $2 \mathrm{mg} \cdot \mathrm{L}^{-1}$ with fully vaporized laboratory-grade hexanal (Sigma-Aldrich Canada Ltd., Oakville, Ont.) before or after wounding. The hexanal was vaporized by heating the liquid hexanal in an aluminum receptacle fitted with a 150-W cartridge heater (Omega Engineering, Stamford, Conn.). The volume that the fruit occupied was $\approx 2.4 \mathrm{~L}$ in the 23 -L chamber. Each fruit was wounded at four locations equidistant over the fruit with a sterile nail (3-mm diameter $\times 3-\mathrm{mm}$ depth) at four locations. The fumigations were done in temperature-controlled rooms at 5, 10, 15, and $20{ }^{\circ} \mathrm{C}$. Fruit was incubated at $20{ }^{\circ} \mathrm{C}$ for $7 \mathrm{~d}$, after which the number of infected wounds was recorded.

Control of postharvest decay in stored 'Anjou' pear. A preliminary trial was conducted in 2001 on 'Anjou' pears picked at commercial maturity from orchards in Wenatchee, Wash., and Summerland, B.C. The fruit was placed in two half-bin replicates (200-kg capacity) and fumigated in an airtight room $(3.0 \times 2.5 \times 3.6 \mathrm{~m})$ originally designed for methyl bromide fumigation. The hexanal was poured into an aluminum frying pan, the room sealed, and the frying pan was set for $120^{\circ} \mathrm{C}$, quickly vaporizing the hexanal in $\approx 15 \mathrm{~min}$, similar to previously reported studies on acetic acid fumigation (Sholberg et al., 2003b). Four large fans circulated the air in the room during the fumigation. The volume of each half bin in the room was $\approx 0.4 \mathrm{~m}^{3}$, occupying less than $2 \%$ of the total room volume. The pears were fumigated at $4 \mathrm{mg} \cdot \mathrm{L}^{-1}$ hexanal for $48 \mathrm{~h}$ at 2 ${ }^{\circ} \mathrm{C}$. Control fruit was placed in $2{ }^{\circ} \mathrm{C}$ cold storage at the same time the rest of the fruit was fumigated. Immediately after fumigation, the chamber was vented and the fruit was removed and placed in $1{ }^{\circ} \mathrm{C}$ cold storage for 7 months. Upon removal from storage, each fruit was examined for decay. Decay categories recorded were tissue and pedicel infection by $B$. cinerea, and $P$. expansum. Fungi that were not obviously one of these two genera were classed as miscellaneous or unknown. Any fruit damage or obvious signs of phytotoxicity such as blackened lenticels were recorded at the same time decay was evaluated.

The PARC 'Anjou' pears harvested from the same trees in 2002 as described earlier for the inoculated trial were also used in the bin trials. The fruit was harvested into boxes and immediately placed at $15{ }^{\circ} \mathrm{C}$ and fumigated at $2 \mathrm{mg} \cdot \mathrm{L}^{-1}$ for $24 \mathrm{~h}$ or $4 \mathrm{mg} \cdot \mathrm{L}^{-1}$ for $18 \mathrm{~h}$. After fumigation, pears were packed in boxes and stored at $1{ }^{\circ} \mathrm{C}$ for 4 months, after which they were rated for decay and phytotoxicity as described previously. In 2003, 'Anjou' pears from PARC were treated with 0 , 0.31 , or $0.62 \mathrm{~g} \cdot \mathrm{L}^{-1}$ cyprodinil 2 weeks before harvest. Each of the three single-tree replicates/treatment (Table 1) were fumigated separately in a $1-\mathrm{m}^{3}$ chamber at $15{ }^{\circ} \mathrm{C}$ for $24 \mathrm{~h}$ as previously described for fumigation of table grapes with acetic acid (Sholberg et al., 1996). Immediately after fumigation, fruit was placed in a $1{ }^{\circ} \mathrm{C}$ cold storage room for 4 months, after which decay and phytotoxicity were recorded as noted earlier.

Control of blue mold in inoculated 'Gala' apples. 'Gala' apples from PARC were treated with $0,0.31$, and $0.62 \mathrm{~g} \cdot \mathrm{L}^{-1}$ cyprodinil 2 weeks before harvest on 30 Aug. 2002 according to a randomized complete block statistical design with three single-tree replicates for each treatment. Subsamples of 10 apples/treatment were used in the inoculated apple fumigation experiments. Penicillium expansum grown on PDA in plastic (10-cmdiameter) Petri plates at $18^{\circ} \mathrm{C}$ for 2 to 3 weeks was used to make a spore suspension containing $1 \times 10^{6} \mathrm{CFU} \cdot \mathrm{mL}^{-1}$. 'Gala' apples were inoculated, wounded, and fumigated as previously described for 'Anjou' pears at $5,10,15$, and $20^{\circ} \mathrm{C}$. In this case the apples were incubated at $25^{\circ} \mathrm{C}$ for $7 \mathrm{~d}$, after which the number of infected wounds was recorded.

Control of postharvest decay in apples. In 2003, 'Gala' apples from PARC were treated with cyprodinil $\left(0,0.31\right.$, or $\left.0.62 \mathrm{~g} \cdot \mathrm{L}^{-1}\right)$ 2 weeks before harvest following the same procedure as used for pears (Table 2). The apples were harvested at commercial maturity and immediately cooled to $15{ }^{\circ} \mathrm{C}$ and fumigated in bins at $3.0 \mathrm{mg} \cdot \mathrm{L}^{-1}$ for $24 \mathrm{~h}$ in the same airtight room used for pears. After fumigation, the room was vented for at least $30 \mathrm{~min}$, after which the apples were placed in standard apple boxes and stored at $1{ }^{\circ} \mathrm{C}$ for 6 months. In addition to the 'Gala' apples, one bin of 'McIntosh' and two bins of 'Jonagold' apples were also fumigated as described and were stored for 5 months at $1{ }^{\circ} \mathrm{C}$. After storage, the 'Gala' apples were ripened for 1 week at $20{ }^{\circ} \mathrm{C}$ and rated for decay. Decay categories recorded were tissue and pedicel infection by $B$. cinerea and $P$. expansum.

Table 1. Percent decay or mold-free 'Anjou' pears fumigated with hexanal and stored for 4 months at $1^{\circ} \mathrm{C}$ in 2003 to 2004 .

\begin{tabular}{lcccc}
\hline Treatment & Stem gray mold & Gray mold & Blue mold & Mold free \\
\hline Cooled fruit $^{\mathrm{z}}$ & $45.0 \mathrm{a}^{\mathrm{v}}$ & $7.0 \mathrm{a}$ & $5.0 \mathrm{a}$ & $33.0 \mathrm{a}$ \\
Cyprodinil cooled fruit $^{\mathrm{y}}$ & $37.5 \mathrm{a}$ & $6.0 \mathrm{a}$ & $0.0 \mathrm{~b}$ & $45.5 \mathrm{a}$ \\
Control fruit $^{\mathrm{x}}$ & $30.5 \mathrm{a}$ & $6.5 \mathrm{a}$ & $4.5 \mathrm{a}$ & $22.0 \mathrm{a}$ \\
Cyprodinil + hexanal $^{\mathrm{w}}$ & $33.5 \mathrm{a}$ & $1.5 \mathrm{~b}$ & $0.0 \mathrm{~b}$ & $53.0 \mathrm{a}$ \\
Cyprodinil $^{\text {Hexanal }}$ & $29.0 \mathrm{a}$ & $1.0 \mathrm{~b}$ & $0.5 \mathrm{~b}$ & $47.5 \mathrm{a}$ \\
\hline
\end{tabular}

${ }^{\mathrm{z}}$ Cooled pears (three replicates) were immediately placed in a $1{ }^{\circ} \mathrm{C}$ cold room after picking.

${ }^{\mathrm{y}}$ Cyprodinil at a concentration of $0.62 \mathrm{~g} \cdot \mathrm{L}^{-1}$ was applied by spraying with a backpack sprayer 2 weeks before harvest.

${ }^{\mathrm{x}}$ Control pears were placed at $15^{\circ} \mathrm{C}$ for $24 \mathrm{~h}$ and then placed in a $1{ }^{\circ} \mathrm{C}$ cold room after picking.

${ }^{\text {w}}$ Fruit were fumigated with $3 \mathrm{mg} \cdot \mathrm{L}^{-1}$ hexanal in bins in a $3.0 \times 2.5 \times 3.6-\mathrm{m}$ room for $24 \mathrm{~h}$ at $15^{\circ} \mathrm{C}$.

${ }^{v}$ Means followed by the same letter in each column are not significantly different according to the WallerDuncan $k$-ratio $t$ test when $k=100$. 
Table 2. Percent infected or mold-free 'Anjou' pears or 'Gala' apples treated before harvest with cyprodinil and fumigated with hexanal.

\begin{tabular}{|c|c|c|c|c|c|c|c|c|}
\hline \multirow[b]{2}{*}{ Treatment $^{z}$} & \multicolumn{2}{|c|}{ Stem gray mold } & \multicolumn{2}{|c|}{ Gray mold } & \multicolumn{2}{|c|}{ Blue mold } & \multicolumn{2}{|c|}{ Mold free } \\
\hline & Anjou & Gala & Anjou & Gala & Anjou & Gala & Anjou & Gala \\
\hline Control & $31.7 a b^{x}$ & $24.0 \mathrm{a}$ & $9.0 \mathrm{ab}$ & $0.5 \mathrm{ab}$ & $13.3 \mathrm{ab}$ & $3.0 \mathrm{a}$ & $37.3 \mathrm{~g}$ & $65.0 \mathrm{abc}$ \\
\hline Hexanal low & $6.3 \mathrm{c}$ & $16.5 \mathrm{a}$ & $9.7 \mathrm{a}$ & $1.0 \mathrm{a}$ & $6.7 \mathrm{bc}$ & $2.5 \mathrm{a}$ & $73.7 \mathrm{bcd}$ & $66.0 \mathrm{abc}$ \\
\hline Hexanal high & $13.7 \mathrm{c}$ & $29.0 \mathrm{a}$ & $6.3 \mathrm{abc}$ & $0.0 \mathrm{~b}$ & $17.0 \mathrm{a}$ & $1.5 \mathrm{a}$ & $61.7 \mathrm{cde}$ & $61.5 \mathrm{abc}$ \\
\hline Cyprodinil $^{\mathrm{y}}$ & $44.3 \mathrm{a}$ & $13.0 \mathrm{a}$ & $2.3 \mathrm{~cd}$ & $1.0 \mathrm{a}$ & $2.7 \mathrm{c}$ & $0.5 \mathrm{a}$ & 56.0 ef & $79.5 \mathrm{ab}$ \\
\hline Cyprodinil + hexanal low & $6.3 \mathrm{c}$ & $10.5 \mathrm{a}$ & $0.3 \mathrm{~d}$ & $0.0 \mathrm{~b}$ & $1.7 \mathrm{c}$ & $1.0 \mathrm{a}$ & $90.0 \mathrm{a}$ & $83.0 \mathrm{a}$ \\
\hline Cyprodinil + hexanal high & $13.0 \mathrm{c}$ & $14.0 \mathrm{a}$ & $5.0 \mathrm{bc}$ & $0.5 \mathrm{ab}$ & $5.0 \mathrm{c}$ & $2.0 \mathrm{a}$ & $75.0 \mathrm{bc}$ & $81.5 \mathrm{ab}$ \\
\hline
\end{tabular}

${ }^{2}$ Fruit was either left untreated or fumigated in bins (400-kg capacity) in a $3.0 \times 2.5 \times 3.6-\mathrm{m}$ room for $24 \mathrm{~h}$ at $2 \mathrm{mg} \cdot \mathrm{L}^{-1}$ (low rate) and $18 \mathrm{~h}$ at $4 \mathrm{mg} \cdot \mathrm{L}^{-1}$ (high rate) hexanal at $15^{\circ} \mathrm{C}$. Each bin replicate (three replicates/treatment) was either fumigated or immediately placed in $1{ }^{\circ} \mathrm{C}$ cold storage. 'Anjou' pears were stored for 4 months in 2002 to 2003 and 'Gala' apples were stored for 6 months in 2003 to 2004.

${ }^{y}$ Cyprodinil was applied to pear fruit and leaves at a concentration of $0.62 \mathrm{~g} \cdot \mathrm{L}^{-1}$ by spraying to drip with a backpack sprayer 2 weeks before harvest.

${ }^{x}$ Means followed by the same letter are not significantly different according to the Waller-Duncan $k$-ratio $t$ test when $k=100$.

randomly selected from PARC employees were asked to rate 'Anjou' pears or 'Gala' apples respectively for intensity of fruit aroma on a $10-\mathrm{cm}$ horizontal line scale. Containers held four fruit/treatment and fruit were tested in random order twice over a 2 -d interval.

\section{Statistical analysis}

Analysis of decay control and properties of hexanal. Individual fruit were considered a replicate for the inoculation experiments whereas box or bin lots were considered as replicates for the postharvest storage experiments. In the inoculation experiments, SE of the mean was calculated for each treatment and graphed; the same software was used for graphing hexanal concentration during fumigation of 'Jonagold' apples and analyzed using nonlinear regression (Prism 4, v. 4.03, GraphPad Software, San Diego). Inoculation study data were further analyzed using a three-way analysis of variance (ANOVA) with interactions between main effects identified with the general linear models (GLM) procedure (SAS Institute, Cary, N.C.), and means were separated using the least significant difference (LSD) test $(P=0.05)$. When a significant interaction occurred between two main effects, one-way ANOVA was performed and means were separated using the LSD test $(P=0.05)$. Results of postharvest decay storage trials, quality, and sensory tests were analyzed with a one-way ANOVA with the GLM procedure. In this case, means were separated using the Waller-Duncan $k$-ratio $t$ test $(k=100)$. Values recorded as percentages were arcsin-transformed before analysis, although only the actual percent values are reported.

\section{Results and Discussion}

\section{Decay control}

Control of gray mold in inoculated 'Anjou' pears. Pears inoculated with $B$. cinerea, followed by fumigation with 2 or $4 \mathrm{mg} \cdot \mathrm{L}^{-1}$ hexanal, then wounding had almost no decay compared with high levels in the control at temperatures ranging from 5 to $20{ }^{\circ} \mathrm{C}$ (Fig. 1A). On the other hand, if fruit were inoculated, wounded, and then fumigated, control was less effective and decay increased at 5 and $20^{\circ} \mathrm{C}$ when compared with nonfumigated fruit (Fig. 1B). Pretreatment of
A Fumigated before wounding

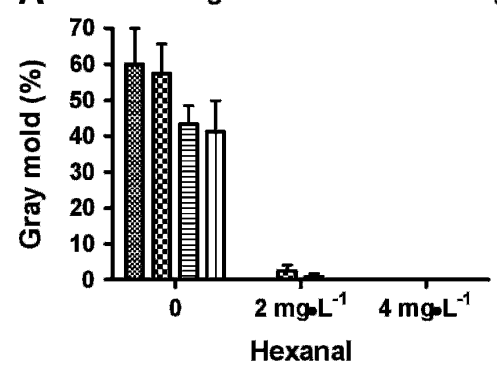

B Fumigated after wounding
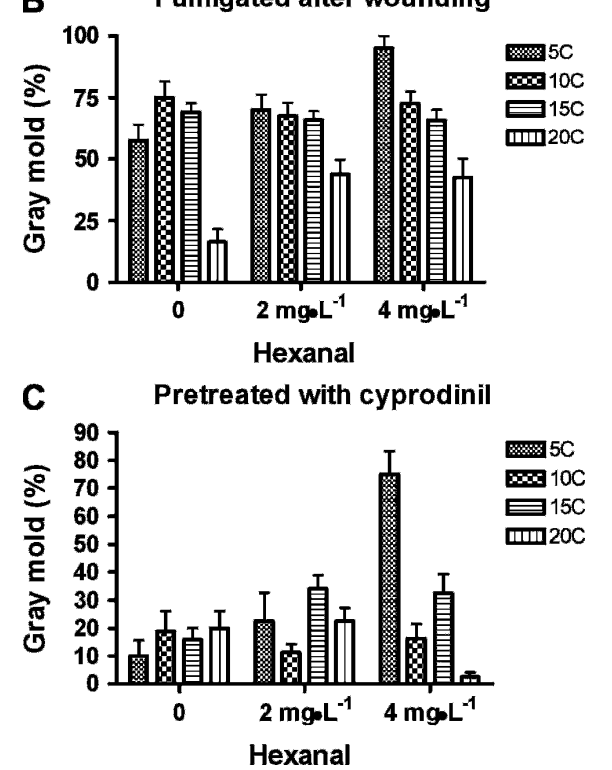

Fig. 1. (A-C) Effect of hexanal fumigation at 2 or $4 \mathrm{mg} \cdot \mathrm{L}^{-1}$ on 'Anjou' pears inoculated with Botrytis cinerea conidia $\left(1 \times 10^{4} \mathrm{CFU} \cdot \mathrm{mL}^{-1}\right)$ and fumigated at $5,10,15$, and $20^{\circ} \mathrm{C}$ before wounding (A), after wounding (B), and after wounding and preharvest treatment with $0.62 \mathrm{~g} \cdot \mathrm{L}^{-1}$ cyprodinil $(\mathbf{C})$. Error bars represent SE of three replications.

pears before harvest with $0.62 \mathrm{~g} \cdot \mathrm{L}^{-1}$ cyprodinil reduced decay by $B$. cinerea when compared with untreated fruit (Fig. 1A, C). The $0.31 \mathrm{~g} \cdot \mathrm{L}^{-1}$ rate of cyprodinil had no effect on apple or pear decay in these inoculation or postharvest trials (data not shown). Fumigation with hexanal significantly increased gray mold in wounded fruit whereas cyprodinil reduced it (Table 3). There was no significant interaction between hexanal treatment and pretreatment with cyprodinil, although tem-
Table 3. Percent infected wounds in 'Anjou' pears or 'Gala' apples treated before harvest with cyprodinil and fumigated after wounding with hexanal at $5,10,15$ and $20^{\circ} \mathrm{C}$.

\begin{tabular}{lcc}
\hline & \multicolumn{2}{c}{ Percent infected } \\
wounds
\end{tabular}

${ }^{2}$ Eighty fruit per treatment were fumigated with hexanal with $2 \mathrm{mg} \cdot \mathrm{L}^{-1}$ for $24 \mathrm{~h}$ and $4 \mathrm{mg} \cdot \mathrm{L}^{-1}$ for $18 \mathrm{~h}$.

${ }^{\mathrm{y}}$ One hundred twenty fruit per treatment were treated with $0.62 \mathrm{~g} \cdot \mathrm{L}^{-1}$ cyprodinil 2 weeks before harvest.

${ }^{\mathrm{x}}$ Sixty fruit per treatment were fumigated in temperature-controlled rooms for 18 to $24 \mathrm{~h}$ at $5,10,15$, and $20^{\circ} \mathrm{C}$.

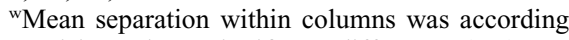
to Fisher's least significant difference (LSD) test at $P=0.05$.

$\mathrm{C}$, cyprodinil; $\mathrm{H}$, hexanal; $\mathrm{T}$, temperature.

perature strongly interacted with both hexanal and cyprodinil. Overall, wounded fruit treated with cyprodinil had the least decay when fumigated at $20{ }^{\circ} \mathrm{C}$. Cyprodinil has previously been shown to reduce decay by $B$. cinerea in apples if applied about 3 weeks before harvest (Sholberg et al., 2003a). Hexanal fumigation prevented infection by spores of $B$. cinerea on the fruit surface, but was ineffective when spores were in wounds. Hexanal likely stimulated germination of spores in wounds at $5^{\circ} \mathrm{C}$, with correspondingly higher rates of decay at $4 \mathrm{mg} \cdot \mathrm{L}^{-1}$ than 
$2 \mathrm{mg} \cdot \mathrm{L}^{-1}$ (Table 3). Fallik et al. (1998) showed that the related compound $(E)-2-$ hexenal would stimulate mycelial growth of $B$. cinerea when used at low concentrations. Apparently hexanal is similar and will stimulate growth of $B$. cinerea conidia in wounds. The effect of temperature was also apparent in these trials, with more than twice as much decay at $5{ }^{\circ} \mathrm{C}$ than at $20{ }^{\circ} \mathrm{C}$ for gray mold (Table 3). The lower amount of decay at 10 , 15 , and $20^{\circ} \mathrm{C}$ was likely the result of a higher vapor pressure generated by hexanal at these temperatures. Gardini et al. (1997) showed that this was the case for Aspergillus niger between 15 and $35{ }^{\circ} \mathrm{C}$, and our results indicate that this is likely the case for $B$. cinerea and $P$. expansum.

Control of postharvest decay in stored pears. Large quantities of 'Anjou' pears from Wenatchee, Wash., that were fumigated in 2001 with $4 \mathrm{mg} \cdot \mathrm{L}^{-1}$ hexanal for $48 \mathrm{~h}$ at $2{ }^{\circ} \mathrm{C}$ had less gray mold than the control fruit (Table 4). Blue mold was controlled in fruit from the second location, but increased in the first location from Washington. Possibly the low fumigation temperature and resulting low vapor pressure were responsible for poor efficacy against blue mold. Fruit storage temperature $\left(-1{ }^{\circ} \mathrm{C}\right)$ after treatment did not affect antifungal activity of trans-2-hexanal against $P$. expansum in 'Conference' pears (Neri et al., 2006b). Fan et al. (2006) found with continuous application of hexanal that at $4{ }^{\circ} \mathrm{C}$, hexanal vapor was low compared with ambient temperature, but fruit lesions incited by $P$. expansum were still substantially reduced, indicating that other factors must be involved. In 2002, preharvest treatment with cyprodinil followed by fumigation with $2 \mathrm{mg} \cdot \mathrm{L}^{-1}$ hexanal provided the highest number of mold-free fruit (Table 2). In 2003, hexanal fumigation reduced both gray and blue molds (Table 1). It appears that hexanal fumigation reduces natural infection of stored 'Anjou' pears, although it is difficult to detect control when disease levels are low.

Table 4. Percent decay or mold-free 'Anjou' pears fumigated with hexanal and stored for 7 months at $1{ }^{\circ} \mathrm{C}$ in 2001 to 2002 .

\begin{tabular}{lccc}
\hline $\begin{array}{l}\text { Treatment and } \\
\text { origin of fruit }\end{array}$ & $\begin{array}{c}\text { Gray } \\
\text { mold }\end{array}$ & $\begin{array}{c}\text { Blue } \\
\text { mold }\end{array}$ & $\begin{array}{c}\text { Mold } \\
\text { free }\end{array}$ \\
\hline $\begin{array}{c}\text { Control } \\
\quad \text { Washington 1 }\end{array}$ & $62.8 \mathrm{a}^{\mathrm{y}}$ & $14.5 \mathrm{~b}$ & $6.0 \mathrm{~d}$ \\
$\begin{array}{c}\text { Hexanal } \\
\quad \text { Washington 1 }\end{array}$ & $7.2 \mathrm{bc}$ & $48.2 \mathrm{a}$ & $6.4 \mathrm{~d}$ \\
$\begin{array}{c}\text { Control } \\
\quad \text { Washington 2 }\end{array}$ & $55.4 \mathrm{a}$ & $14.9 \mathrm{~b}$ & $14.2 \mathrm{c}$ \\
$\begin{array}{c}\text { Hexanal } \\
\quad \text { Washington 2 }\end{array}$ & $15.6 \mathrm{~b}$ & $4.0 \mathrm{c}$ & $46.6 \mathrm{a}$ \\
$\begin{array}{c}\text { Control British } \\
\text { Columbia }\end{array}$ & $5.8 \mathrm{bc}$ & $1.1 \mathrm{~d}$ & $32.5 \mathrm{~b}$ \\
$\begin{array}{c}\text { Hexanal British } \\
\text { Columbia }\end{array}$ & $5.2 \mathrm{c}$ & $2.4 \mathrm{~cd}$ & $29.4 \mathrm{~b}$ \\
\hline
\end{tabular}

${ }^{\text {zPears were obtained from two locations near }}$ Wenatchee, Wash., or one location in Summerland, B.C. The fruit was either left untreated or fumigated with $4 \mathrm{mg} \cdot \mathrm{L}^{-1}$ hexanal in bins (200-kg capacity/bin) in a $3.0 \times 2.5 \times 3.6-\mathrm{m}$ room for $48 \mathrm{~h}$ at $2{ }^{\circ} \mathrm{C}$.

${ }^{\mathrm{y}}$ Means followed by the same letter in each column are not significantly different according to the Waller-Duncan $k$-ratio $t$ test when $k=100$.
Based on these results and previous research, fumigation should be conducted at 15 to $20^{\circ} \mathrm{C}$ for $24 \mathrm{~h}$ as early as possible after the fruit are harvested and again before the pears are handled for packing. Additionally, an effective systemic preharvest treatment such as cyprodinil or pyrimethanil (Sholberg et al., 2005) should be used to protect wounds from decay because low rates of hexanal are ineffective on spores in wounds and could actually stimulate their growth (Fallik et al., 1998) (Table 3). Postharvest treatment with fludioxonil or pyrimethanil could also be used to prevent decay in wounds, although pyrimethanil should not be used if it is used as a preharvest treatment. Resistance management is very important with these new postharvest fungicides, and hexanal could provide another mode of action for use in alteration with fludioxonil and pyrimethanil.

Control of blue mold in inoculated 'Gala' apples. Fruit inoculated with $P$. expansum, followed by fumigation with 2 or $4 \mathrm{mg} \cdot \mathrm{L}^{-1}$ hexanal, then wounding had the least decay at $15{ }^{\circ} \mathrm{C}$ with 2 or $4 \mathrm{mg} \cdot \mathrm{L}^{-1}$ hexanal (Fig. $2 \mathrm{~A}$ ). The treatment was less effective on fruit
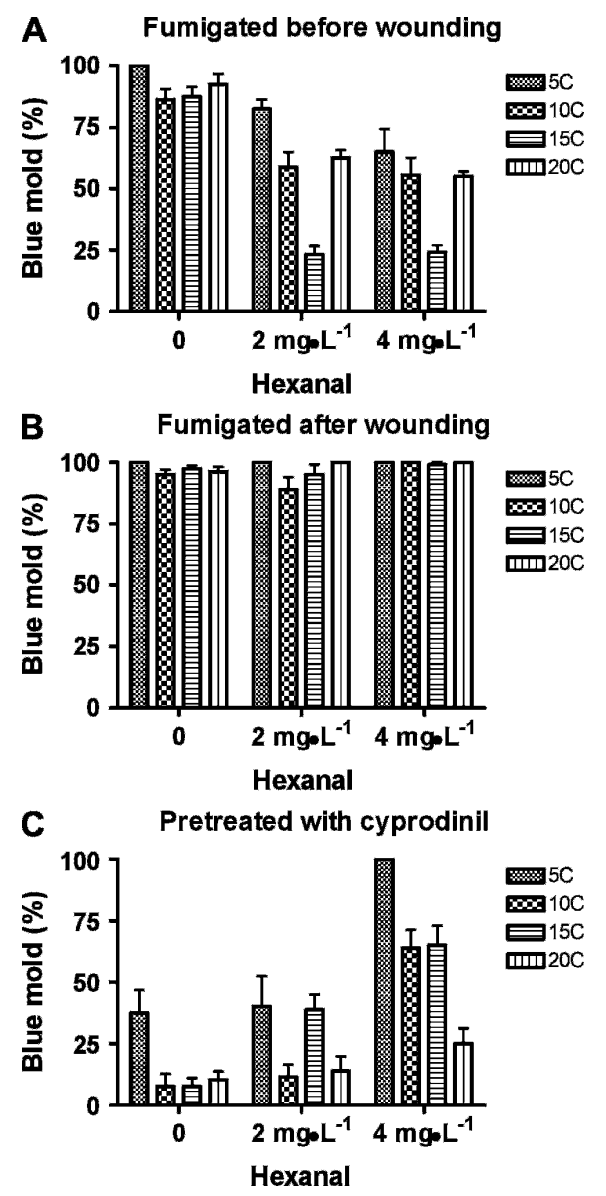

Fig. 2. (A-C) Effect of hexanal fumigation at 2 or $4 \mathrm{mg} \cdot \mathrm{L}^{-1}$ on 'Gala' apples inoculated with Penicillium expansum conidia $\left(1 \times 10^{6}\right.$ $\mathrm{CFU} \cdot \mathrm{mL}^{-1}$ ) and fumigated at $5,10,15$, and $20{ }^{\circ} \mathrm{C}$ before wounding (A), after wounding (B), and after wounding and preharvest treatment with $0.62 \mathrm{~g} \cdot \mathrm{L}^{-1}$ cyprodinil $(\mathbf{C})$. Error bars represent SE of three replications. fumigated at $5{ }^{\circ} \mathrm{C}$ (Table 3 ), probably because of its low vapor pressure at this temperature (Gardini et al., 1997). As in the case of gray mold, there was significant interaction of blue mold between temperature and hexanal, and temperature and cyprodinil $\left(0.62 \mathrm{~g} \cdot \mathrm{L}^{-1}\right)$. In addition there was a significant interaction between hexanal and cyprodinil with blue mold. Analysis of this interaction showed that pretreatment with cyprodinil significantly improved control of blue mold, but application of hexanal decreased the effect of cyprodinil in proportion to the concentration of hexanal. Thus the high rate of hexanal allowed $68 \%$ decay; the low rate, $21 \%$; and the zero rate, $10 \%$; in apples that had been pretreated with cyprodinil. In laboratory studies Neri et al. (2006c) showed that blue mold of apples and pears was controlled when fruit was wound-inoculated and fumigated continuously over a $24-\mathrm{h}$ period with trans-2-hexenal at a concentration of $12.5 \mu \mathrm{L} \cdot \mathrm{L}^{-1}$. Continuous exposure to the fumigant at a constant rate appears necessary for control of $P$. expansum conidia in wounds. In this study, if fruit were inoculated, wounded, and then fumigated, there was no decay control (Fig. 2B). On the other hand, 'Gala' apples inoculated with P. expansum that had been treated before harvest with cyprodinil had $60 \%$ less decay than fruit that was not treated with cyprodinil (Fig. 2C; Table 3). Zhou et al. (2002) showed that cyprodinil controlled blue and gray molds by more than $90 \%$ at concentrations of 25 and $5 \mu \mathrm{g} \cdot \mathrm{mL}^{-1}$ respectively on apples. As previously found for $B$. cinerea, hexanal can also increase blue mold decay (Table 3 ). Analysis of the interaction of temperature with hexanal showed that the high rate of hexanal increased decay at 5,10 , and $15{ }^{\circ} \mathrm{C}$ when compared with the lower rate and the control. Neri et al. (2006a) also reported that low concentrations of the hexanal-related compound trans-2-hexenal enhanced conidial germination of $P$. expansum.

Control of postharvest decay in stored apples. Fruit pretreated with cyprodinil $0.62 \mathrm{~g} \cdot \mathrm{L}^{-1}$ and fumigated with hexanal generally had less mold than fruit not treated with hexanal or cyprodinil, but did not differ significantly from the control (Table 2). 'Gala' apples treated with hexanal after storage for 5 months, then wounded to promote decay, developed $\approx 10 \%$ less decay than the control fruit whether previously fumigated or not fumigated at harvest (Table 5). Results for both 'McIntosh' and 'Jonagold' apples were not significantly different from nonfumigated fruit, probably because levels of contamination were very low. It appears that fumigation with hexanal after storage sterilizes the apple surface, reducing the chance that decay will occur by wounding. Similar results were obtained by fumigating apples with acetic acid (Sholberg et al., 2001). Fumigation with $10 \mu \mathrm{L} \cdot \mathrm{L}^{-1}$ acetic acid reduced the percentage of decayed puncture wounds in six apple cultivars to levels less than $10 \%$ after the fruit had been stored at $1{ }^{\circ} \mathrm{C}$ for several months. 
Table 5. Percent infection and decay of wounded 'Gala' apples stored in bins fumigated with hexanal before and after storage at $1{ }^{\circ} \mathrm{C}$ for 5 months in 2003 to 2004 .

\begin{tabular}{|c|c|c|c|}
\hline Treatment $^{\mathrm{z}}$ & $\begin{array}{c}\text { When } \\
\text { fumigated }\end{array}$ & $\begin{array}{c}\text { Infected } \\
\text { wounds }(\%)\end{array}$ & $\begin{array}{c}\text { Decay } \\
(\%)\end{array}$ \\
\hline Control & Not fumigated & $29.8 \mathrm{a}^{\mathrm{y}}$ & $10.5 \mathrm{a}$ \\
\hline Hexanal & At harvest & $26.8 \mathrm{a}$ & $10.8 \mathrm{a}$ \\
\hline Hexanal & $\begin{array}{l}\text { At harvest and } \\
\text { after storage }\end{array}$ & $3.2 \mathrm{~b}$ & $1.2 \mathrm{~b}$ \\
\hline Hexanal & After storage & $2.5 \mathrm{~b}$ & $0.8 \mathrm{~b}$ \\
\hline
\end{tabular}

zFruit in bins were immediately fumigated after harvest with $3 \mathrm{mg} \cdot \mathrm{L}^{-1}$ hexanal for $24 \mathrm{~h}$ in a $3.0 \times$ $2.5 \times 3.6-\mathrm{m}$ room at $15^{\circ} \mathrm{C}$ and stored in a $1{ }^{\circ} \mathrm{C}$ cold room for 5 months. After storage they were allowed to warm to $15{ }^{\circ} \mathrm{C}$ for $24 \mathrm{~h}$ and fumigated with $3 \mathrm{mg} \cdot \mathrm{L}^{-1}$ hexanal for $24 \mathrm{~h}$. Subsamples of 10 fruit/ replicate were aseptically wounded and placed at $20{ }^{\circ} \mathrm{C}$ for 1 week, when percent infected wounds was recorded.

${ }^{y}$ Means followed by the same letter in each column are not significantly different according to the Waller-Duncan $k$-ratio $t$ test when $k=100$.

\section{Hexanal properties}

Monitoring hexanal during fumigation. Hexanal vaporized completely, as recorded by the gas chromatograph during fumigation, whether in small $23-\mathrm{L}$ chambers, larger $1-\mathrm{m}^{3}$ chambers, or in the $27-\mathrm{m}^{3}$ room. During fumigation of 'Jonagold' apples on two different dates during the first $4 \mathrm{~h}$, the decline in hexanal concentration was not significantly different at any of the time points except at the 0.5-h time point (Fig. 3). Analysis of the data for fumigations on 2 and 6 Oct. 2003 using nonlinear regression showed that third-order polynomial equations would describe the data, with $R^{2}$ values of 0.9762 and 0.9803 respectively. The equations for 2 and 6 Oct. respectively were $\mathrm{y}=$ $2.934-0.2996 \mathrm{x}+0.01343 \mathrm{x}^{2}-0.0002092 \mathrm{x}^{3}$ and $\mathrm{y}=3.064-0.3317 \mathrm{x}+0.01655 \mathrm{x}^{2}-$ $0.0003005 \mathrm{x}^{3}$, where $\mathrm{y}$ is milligrams per liter of hexanal and $\mathrm{x}$ is hours.

Effect of hexanal on fruit quality. Fruit quality in 'Anjou' pears as indicated by firmness, $\mathrm{pH}$, soluble solids, or titratable acidity was not significantly different among any of the treatments shortly after harvest on 1 Oct. 2003 (Table 6). After the fruit had been stored for $83 \mathrm{~d}$, the fruit firmness in the control fruit and noncooled cyprodinil-

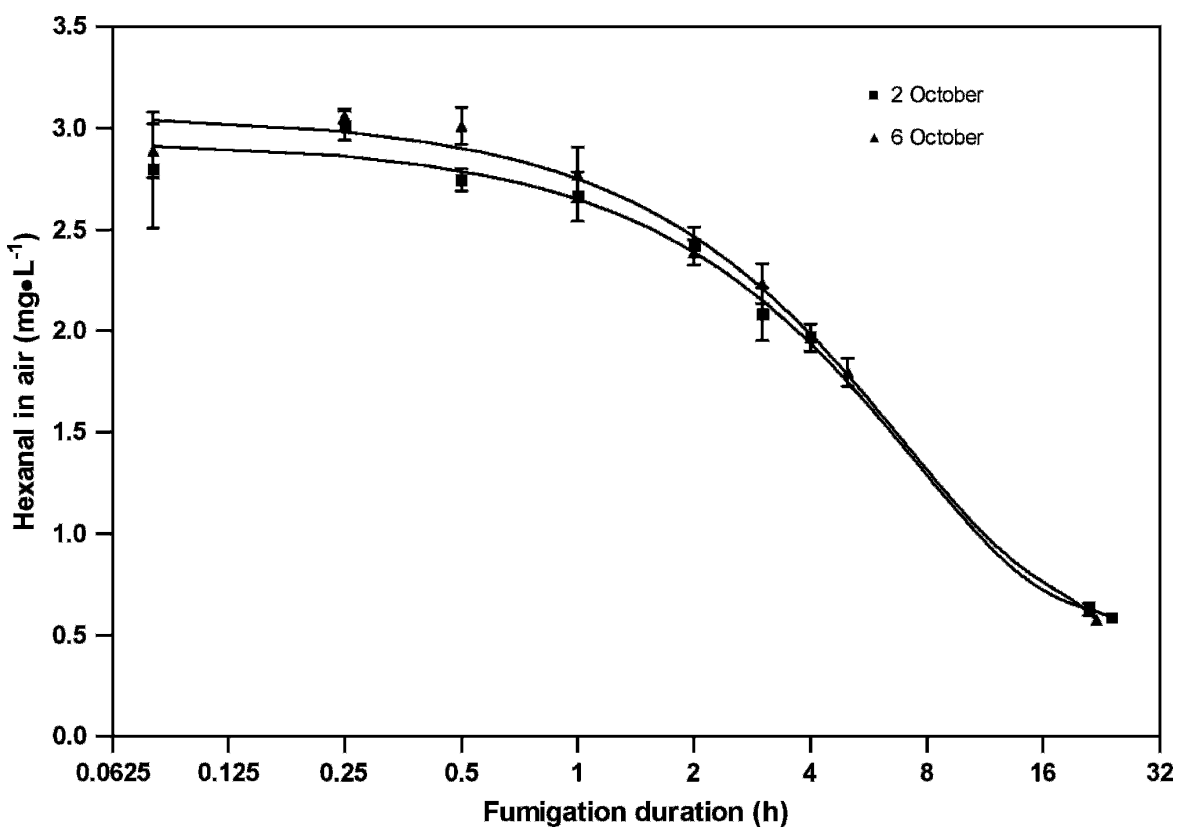

Fig. 3. Effect of time (in hours) on concentration of hexanal (in milligrams per liter) in air when 'Jonagold' apples occupying a volume of $0.38 \mathrm{~m}^{3}$ were fumigated in a $27-\mathrm{m}^{3}$ room with $3 \mathrm{mg} \cdot \mathrm{L}^{-1}$ hexanal for $24 \mathrm{~h}$ on 2 and 6 Oct. 2003. Error bars represent SD of four replications.

treated fruit was lower than any of the other treatments, indicating that fumigation with hexanal or immediately cooling the fruit could improve fruit firmness. However, this trend did not last, and after $112 \mathrm{~d}$, none of the treatments were significantly different from one another.

Hexanal-fumigated 'Anjou' pears and 'Gala' apples had fruitier aromas than nonfumigated pears $(\operatorname{Pr}>\mathrm{F}=0.0002)$ or apples. The apple aroma did not develop until the second day, when apples treated with $2 \mathrm{mg} \cdot \mathrm{L}^{-1}$ hexanal for $24 \mathrm{~h}$ had a significantly fruitier aroma $(\mathrm{Pr}>\mathrm{F}=0.0010)$ than either nonfumigated 'Gala' apples or those fumigated for $18 \mathrm{~h}$ with $4 \mathrm{mg} \cdot \mathrm{L}^{-1}$ hexanal. This result also continued into the third day of rating by the judges $(\operatorname{Pr}>F=0.0002)$. Song et al. (1998) found that hexanal treatment stimulated aroma volatile production in 'Jonagold' and 'Golden Delicious' apple slices, with hexanal actively converted into the aroma volatiles hexanol and hexylacetate after 20 to
$30 \mathrm{~h}$ of treatment. Fruit of a number of important plant species use $\mathrm{C}_{6}$-aldehydes as precursors to aromas (Song et al., 1996). Our results with sensory evaluation of both 'Gala' apples and 'Anjou' pears support this finding for hexanal applied immediately after harvest.

Damage of fruit by hexanal fumigation. Hexanal concentrations more than $8 \mathrm{mg} \cdot \mathrm{L}^{-1}$ were phytotoxic to 'Anjou' pears, causing black discoloration over the entire fruit surface (Table 7). In 'Gala' and 'Golden Delicious' apples, hexanal used at $12 \mathrm{mg} \cdot \mathrm{L}^{-1}$ for $48 \mathrm{~h}$ at $1{ }^{\circ} \mathrm{C}$ or $2 \mathrm{mg} \cdot \mathrm{L}^{-1}$ for $48 \mathrm{~h}$ at $20^{\circ} \mathrm{C}$ was also phytotoxic and caused a scaldlike discoloration of the fruit. 'Red Delicious' apples were resistant to damage by hexanal and were only damaged by $15 \mathrm{mg} \cdot \mathrm{L}^{-1}$ for $48 \mathrm{~h}$ at $1^{\circ} \mathrm{C}$ or $4 \mathrm{mg} \cdot \mathrm{L}^{-1}$ for $48 \mathrm{~h}$ at $20^{\circ} \mathrm{C}$. Three milligrams/ liter of hexanal for $24 \mathrm{~h}$ at $20{ }^{\circ} \mathrm{C}$ did not damage apples or pears, although $4 \mathrm{mg} \cdot \mathrm{L}^{-1}$ for $18 \mathrm{~h}$ damaged 'Golden Delicious' apples. Caccioni et al. (1995) found that hexanal at

Table 6. Effect of cooling, preharvest treatment with cyprodinil, and fumigation with hexanal on 'Anjou' pear quality after 0 , 83 , and $112 \mathrm{~d}$ storage at $1{ }^{\circ} \mathrm{C}$.

\begin{tabular}{|c|c|c|c|c|c|c|c|c|c|}
\hline \multirow[b]{2}{*}{ Treatment } & \multicolumn{4}{|c|}{$0 \mathrm{~d}$} & \multicolumn{4}{|c|}{$83 \mathrm{~d}$} & \multirow{2}{*}{$\begin{array}{c}112 \mathrm{~d} \\
\text { Firm. }(\mathrm{kg})\end{array}$} \\
\hline & Firm. $^{\mathrm{z}}(\mathrm{kg})$ & $\mathrm{pH}$ & ${ }^{\circ}$ Brix $^{y}$ & $\mathrm{TA}^{\mathrm{x}}\left(\mathrm{mg} \cdot \mathrm{L}^{-1}\right)$ & Firm. (kg) & $\mathrm{pH}$ & ${ }^{\circ}$ Brix & $\mathrm{TA}\left(\mathrm{Mg} \cdot \mathrm{L}^{-1}\right)$ & \\
\hline Cooled fruit $^{\mathrm{w}}$ & $5.2 \mathrm{a}^{\mathrm{s}}$ & $3.8 \mathrm{a}$ & $12.3 \mathrm{a}$ & $8.3 \mathrm{a}$ & $4.8 \mathrm{a}$ & $3.4 \mathrm{ab}$ & $12.6 \mathrm{a}$ & $7.0 \mathrm{a}$ & $4.7 \mathrm{a}$ \\
\hline Cyprodinil + cooled fruit ${ }^{v}$ & $5.1 \mathrm{a}$ & $3.6 \mathrm{a}$ & $11.9 \mathrm{a}$ & $7.7 \mathrm{a}$ & $4.8 \mathrm{a}$ & $3.5 \mathrm{a}$ & $11.6 \mathrm{c}$ & $5.8 \mathrm{a}$ & $4.0 \mathrm{a}$ \\
\hline Control $^{\mathrm{u}}$ & $5.2 \mathrm{a}$ & $3.7 \mathrm{a}$ & $13.2 \mathrm{a}$ & $8.5 \mathrm{a}$ & $2.3 \mathrm{~b}$ & $3.3 \mathrm{~b}$ & $12.5 \mathrm{ab}$ & $6.7 \mathrm{a}$ & $3.6 \mathrm{a}$ \\
\hline 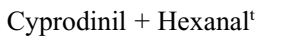 & $5.1 \mathrm{a}$ & $3.7 \mathrm{a}$ & $13.1 \mathrm{a}$ & $8.7 \mathrm{a}$ & $4.1 \mathrm{a}$ & $3.5 \mathrm{a}$ & $11.8 \mathrm{bc}$ & $6.4 \mathrm{a}$ & $3.7 \mathrm{a}$ \\
\hline Cyprodinil & $5.1 \mathrm{a}$ & $3.6 \mathrm{a}$ & $12.4 \mathrm{a}$ & $7.9 \mathrm{a}$ & $2.8 \mathrm{~b}$ & $3.4 \mathrm{ab}$ & $12.4 \mathrm{ab}$ & $7.1 \mathrm{a}$ & $3.9 \mathrm{a}$ \\
\hline Hexanal & $5.5 \mathrm{a}$ & $3.8 \mathrm{a}$ & $13.1 \mathrm{a}$ & $8.9 \mathrm{a}$ & $4.8 \mathrm{a}$ & $3.6 \mathrm{a}$ & $12.4 \mathrm{ab}$ & $6.3 \mathrm{a}$ & $4.7 \mathrm{a}$ \\
\hline
\end{tabular}

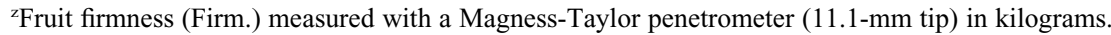

${ }^{y}$ Soluble solids measured with a refractometer.

xTitratable acidity (TA) as determined by titration $(\mathrm{pH}, 8.1)$.

${ }^{\mathrm{w}}$ Cooled pears were immediately placed in a $1{ }^{\circ} \mathrm{C}$ cold room after picking.

${ }^{\mathrm{v}}$ Cyprodinil at a concentration of $0.62 \mathrm{~g} \cdot \mathrm{L}^{-1}$ was applied to pear fruit and leaves by spraying to drip with a backpack sprayer 2 weeks before harvest.

"Control pears were placed at $15^{\circ} \mathrm{C}$ for $24 \mathrm{~h}$ and then placed in a $1{ }^{\circ} \mathrm{C}$ cold room after picking.

${ }^{\mathrm{t}}$ Fruit was fumigated in bins $\left(400-\mathrm{kg}\right.$ capacity) in a $3.0 \times 2.5 \times 3.6-\mathrm{m}$ room for $24 \mathrm{~h}$ at $3 \mathrm{mg} \cdot \mathrm{L}^{-1}$ hexanal at $15{ }^{\circ} \mathrm{C}$.

${ }^{\mathrm{x}}$ Means followed by the same letter are not significantly different according to the Waller-Duncan $k$-ratio $t$ test when $k=100$. 
Table 7. Phytotoxicity present in pome fruit treated with hexanal at different rates and temperatures.

\begin{tabular}{|c|c|c|c|c|c|c|c|c|c|}
\hline \multirow[b]{2}{*}{ Cultivar $^{2}$} & \multicolumn{4}{|c|}{ Fumigation at $1{ }^{\circ} \mathrm{C}$} & \multicolumn{5}{|c|}{ Fumigation at $20^{\circ} \mathrm{C}$} \\
\hline & $\begin{array}{c}48 \mathrm{~h}, \\
4 \mathrm{mg} \cdot \mathrm{L}^{-1}\end{array}$ & $\begin{array}{c}48 \mathrm{~h}, \\
8 \mathrm{mg} \cdot \mathrm{L}^{-1}\end{array}$ & $\begin{array}{c}48 \mathrm{~h}, \\
12 \mathrm{mg} \cdot \mathrm{L}^{-1}\end{array}$ & $\begin{array}{c}48 \mathrm{~h}, \\
15 \mathrm{mg} \cdot \mathrm{L}^{-1}\end{array}$ & $\begin{array}{c}48 \mathrm{~h}, \\
2 \mathrm{mg} \cdot \mathrm{L}^{-1}\end{array}$ & $\begin{array}{c}48 \mathrm{~h}, \\
4 \mathrm{mg} \cdot \mathrm{L}^{-1}\end{array}$ & $\begin{array}{c}24 \mathrm{~h} \\
2 \mathrm{mg} \cdot \mathrm{L}^{-1}\end{array}$ & $\begin{array}{c}24 \mathrm{~h}, \\
3 \mathrm{mg} \cdot \mathrm{L}^{-1}\end{array}$ & $\begin{array}{c}18 \mathrm{~h} \\
4 \mathrm{mg} \cdot \mathrm{L}^{-1}\end{array}$ \\
\hline$\overline{\text { Anjou }}$ & No & No & Yes & Yes & Yes & Yes & No & No & No \\
\hline Red & No & No & No & Yes & No & Yes & No & No & No \\
\hline
\end{tabular}

${ }^{\mathrm{z}}$ Observations are based on fumigation trials conducted in 23-L chambers or in the $27-\mathrm{m}^{3}$ room from 2001 to 2005.

rates more than 2500 ppm was phytotoxic on stone fruit, but effectively controlled M. laxa and $R$. stolonifer at rates that did not damage the fruit. In this study, large volumes of fruit were fumigated with 2 to $4 \mathrm{mg} \cdot \mathrm{L}^{-1}$ hexanal consistently during the 3 years of the study without causing fruit damage. Phytotoxicity was only experienced when fruit was fumigated at 1 to $2{ }^{\circ} \mathrm{C}$ for $48 \mathrm{~h}$ or when it was fumigated at warmer temperatures for more than 24 h. Only in 'Abate Fetel' pears did phytotoxic symptoms develop within $3 \mathrm{~d}$ of treatment with trans-2-hexenal of several apple and pear cultivars tested by Neri et al. (2006c). In contrast to hexanal, acetic acid vapor was much more phytotoxic to 'Anjou' pears, leaving very little room for error when applied at $2{ }^{\circ} \mathrm{C}$ (Sholberg et al., 2004).

\section{Literature Cited}

Archbold, D.D., T.R. Hamilton-Kemp, M.M. Barth, and B.E. Langlois. 1997. Identifying natural volatile compounds that control gray mold (Botrytis cinerea) during postharvest storage of strawberry, blackberry, and grape. J. Agr. Food Chem. 45:4032-4037.

Archbold, D.D., T.R. Hamilton-Kemp, A.M. Clements, and R.W. Collins. 1999. Fumigating 'Crimson Seedless' table grapes with (E)-2-hexenal reduces mold during longterm postharvest storage. HortScience 34: 705-707.

Archbold, D.D., T.R. Hamilton-Kemp, and E. Fallik. 2000. Aroma volatiles as modulators of postharvest mold development on fruit: In vivo role and fumigation tools. Acta Hort. 518:87-92.

Caccioni, D.R.L., G. Tonini, and M. Guizzardi. 1995. Antifungal activity of stone fruit aroma compounds against Monilinia laxa (Aderh. Et Ruhl.) honey and Rhizopus stolonifer (Ehrenb.): In vivo trials. J. Plant Dis. Protect. 102:518-525.

Fallik, E., D.D. Archbold, T.R. Hamilton-Kemp, A.M. Clements, R.W. Collins, and M.M. Barth. 1998. (E)-2-hexenal can stimulate Botrytis cinerea growth in vitro and on strawberries in vivo during storage. J. Amer. Soc. Hort. Sci. 123:875-881.
Fan, L., J. Song, R.M. Beaudry, and P.D. Hildebrand. 2006. Effect of hexanal vapor on spore viability of Penicillium expansum, lesion development on whole apples and fruit volatile biosynthesis. J. Food Sci. 71:M105-M109.

Gardini, F., R. Lanciotti, D.R.L. Caccioni, and M.E. Guerzoni. 1997. Antifungal activity of hexanal as dependent on its vapor pressure. J. Agr. Food Chem. 45:4297-4302.

Hamilton-Kemp, T.R., C.T. McCracken, Jr., J.H. Loughrin, R.A. Andersen, and D.F. Hildebrand. 1992. Effects of some natural volatile compounds on the pathogenic fungi Alternaria alternata and Botrytis cinerea. J. Chem. Ecol. 18:1083-1091.

Hildebrand, D.F. 1989. Lipoxygenases. Physiol. Plant Physiol. 76:249-253.

Lanciotti, R., M.R. Corbo, F. Gardini, M. Sinigaglia, and M.E. Guerzoni. 1999. Effect of hexanal on the shelf life of fresh apple slices. J. Agr. Food Chem. 47:4769-4776.

Lennox, C.L., R.A. Spotts, and M. Booyse. 2004. Incidence of postharvest decay of d'Anjou' pear and control with a thiabendazole drench Plant Dis. 88:474-478.

Neri, F., M. Mari, and S. Brigati. 2006a. Control of Penicillium expansum by plant volatile compounds. Plant Pathol. 55:100-105.

Neri, F., M. Mari, A.M. Menniti, and S. Brigati. 2006b. Activity of trans-2-hexenal against Penicillium expansum in 'Conference' pears. J. Appl. Microbiol. 100:1186-1193.

Neri, F., M. Mari, A.M. Menniti, S. Brigati, and P. Bertolini. 2006c. Control of Penicillium expansum in pears and apples by trans-2-hexenal vapours. Postharvest Biol. Technol. 41:101108.

Ogawa, J.M. and H. English. 1991. Diseases of temperate zone tree fruit and nut crops. Publication no. 3345. University of California, Division of Agriculture and Natural Resources, Oakland, Calif.

Rosenberger, D.A. 1990. Gray mold, p. 55-56 In: A.L. Jones and H.S. Aldwinckle (eds.). Compendium of apple and pear diseases American Phytopathological Society Press, St. Paul, Minn.

Sholberg, P.L., K.E. Bedford, and S. Stokes. 2003a. Effect of preharvest application of cyprodinil on postharvest decay of apples caused by Botrytis cinerea. Plant Dis. 87:1067-1071.
Sholberg, P.L., K.E. Bedford, and S. Stokes. 2005. Sensitivity of Penicillium spp. and Botrytis cinerea to pyrimethanil and its control of blue and gray mold of stored apples. Crop Prot. 24:127-134.

Sholberg, P.L., M. Cliff, and A.L. Moyls. 2001. Fumigation with acetic acid vapour to control decay of stored apples. Fruits 56: 355-366.

Sholberg, P., P. Haag, R. Hocking, and K. Bedford. 2000. The use of vinegar vapor to reduce postharvest decay of harvested fruit. HortScience 35:898-903.

Sholberg, P. and P. Randall. 2005. Hexanal vapor for postharvest decay and aroma production in stored pome fruit. Phytopathology 95:S96.

Sholberg, P.L., A.G. Reynolds, and A.P. Gaunce. 1996. Fumigation of table grapes with acetic acid to prevent postharvest decay. Plant Dis. 80:1425-1428.

Sholberg, P., T. Shephard, and L. Moyls. 2003b. Monitoring acetic acid vapour concentrations during fumigation of fruit for control of post harvest decay. Can. Biosystems Eng. 45:313317.

Sholberg, P.L., T. Shephard, P. Randall, and L. Moyls. 2004. Use of measured concentrations of acetic acid vapour to control postharvest decay in d'Anjou pears. Postharvest Biol. Technol. 32:89-98.

Song, J., R. Leepipattanawit, W. Deng, and R.M. Beaudry. 1996. Hexanal vapor is a natural, metabolizable fungicide: Inhibition of fungal activity and enhancement of aroma biosynthesis in apple slices. J. Amer. Soc. Hort. Sci. 12:937-942.

Song, J., R. Leepipattanawit, W. Deng, and R.M. Beaudry. 1998. Hexanal vapor acts as residueless antifungal agent that enhances aroma biosynthesis in apple fruit. Acta Hort. 464: 219-224.

Turechek, W.W. 2004. Apple diseases and their management, p. 1-108. In: S.A.M.H. Naqvi (ed.). Diseases of fruits and vegetables. Vol. 1. Kluwer Academic Publishers, Dordrecht, the Netherlands.

Zhou, T., J. Northover, K.E. Schneider, and X. Lu. 2002. Interactions between Pseudomonas syringae MA-4 and cyprodinil in the control of blue mold and gray mold of apples. Can. J. Plant Pathol. 24:154-161. 